\title{
Nationwide PCB congener pattern analysis in freshwater fish samples in France
}

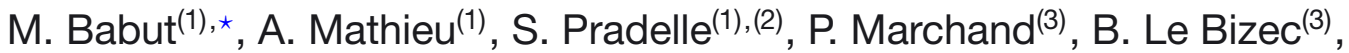 \\ O. Perceval( ${ }^{(4)}$
}

Received September 13, 2012

Revised December 7, 2012

Accepted January 4, 2013

Key-words:

PCB,

fish,

congener

pattern,

statistics,

metabolism

\section{ABSTRACT}

The 2006 european directive on polychlorodibenzodioxins and related compounds in foodstuffs prompted in France a nationwide monitoring study of freshwater fish contamination by these compounds. A database covering about 300 sites (2848 samples of 36 fish species) was obtained from this study. This database was used to explore congener pattern distributions, in order to identify typical sources and the impact of biotransformation on these sources. Fish ecological traits and fish size are the main factors explaining the overall PCB contamination in the two pre-identified categories of species (high or low propensity to accumulate hydrophobic compounds). Lipid content is also an influencing factor, but its relationship to other factors remains uncertain. Species show distinct congener patterns, related more to their physiology than to ecological traits. Spatial patterns were studied on selected sites having more than five individuals analysed - either chub (Squalius cephalus) or barbel (Barbus barbus), the most widespread species in the database -. We identified six patterns, which mainly differed in the respective proportions of congeners potentially biotransformed by fish. No connection to typical sources, e.g. technical mixtures, was identified. These patterns instead represent an ageing path of the initial mixtures; they could be used for setting remediation priorities.

\section{RÉSUMÉ}

Analyse à l'échelle nationale des profils de congénères de PCB dans la chair de poissons d'eau douce en France
Mots-clés :
La directive européenne fixant les teneurs maximales des polychlorodibenzo- PCB,
poisson,
profil dioxines et composés apparentés dans les denrées alimentaires, publiée en 2006, a provoqué en France la mise en œuvre à l'échelle nationale d'une étude sur la contamination des poissons d'eau douce par ces composés. II en a résulté une de congénères, statistiques, métabolisme base de données incluant plus de 300 sites (2848 échantillons provenant de 36 es- pèces de poisson). Cette base de données a été utilisée pour explorer la distribu- tion de profils de congénères, afin d'identifier des profils typiques de sources, ainsi que l'impact des processus de biotransformation sur ces sources. La taille des poissons et des traits écologiques comme la position dans le cours d'eau et le comportement alimentaire sont les principaux facteurs explicatifs du niveau de contamination par les PCB dans les deux catégories pré-identifiées d'espèces

(1) Irstea, UR MALY, 3 bis Quai Chauveau - CP220, 69336 Lyon, France

(2) DREAL Rhône-Alpes, Délégation de bassin, 69453 Lyon, France

(3) LABERCA, ONIRIS, 44307 Nantes, France

(4) ONEMA, DAST, 94300 Vincennes, France

* Corresponding author: marc.babut@irstea.fr 
(tendance forte/faible à l'accumulation de composés hydrophobes). Le taux de lipides dans la chair musculaire des poissons exerce également une influence, dont la relation aux autres facteurs reste incertaine. Les profils de congénères diffèrent selon l'espèce, ce qui s'explique mieux par leur physiologie que par les traits écologiques mentionnés. Pour étudier les différences spatiales de profil, nous avons sélectionné les sites pour lesquels au moins 5 échantillons individuels de chevaine (Squalius cephalus) ou de barbeau (Barbus barbus) étaient disponibles. Six profils types ont été identifiés; ceux-ci diffèrent principalement par les proportions respectives de congénères potentiellement biotransformables par les poissons. II n'a pas été possible d'identifier de profil typique de mélange technique. Ces profils types représentent plutôt des étapes dans l'évolution temporelle de la contamination; ils pourraient être utilisés pour établir des priorités en matière de remédiation.

\section{INTRODUCTION}

Initially viewed as "miraculous" substances suitable for multiple purposes, polychlorobiphenyls (PCBs) were then contested due to their persistence in the environment, their propensity to biomagnify along food webs, and their toxicity to human beings and wildlife (Koppe and Keys, 2001). PCB uses have been restricted in many countries since the 1970s and prohibited since the 1980s. PCBs were prohibited in 1987 in France, except in closed equipment, where use of PCBs was authorised until 2010 (E.C., 1996).

Concentrations declined rapidly after banning, in biota (French et al., 2006; Hickey et al., 2006) as well as in other compartments (Schneider et al., 2001). The decline is at present much slower, or even absent (Bhavsar et al., 2007c; Carlson et al., 2010). Nevertheless PCBs today remain a concern in French rivers. The 2006 European directive on polychlorodibenzodioxins (PCDDs) and related compounds in foodstuffs (E.C., 2006). set a threshold of $8 \mathrm{pg} \cdot \mathrm{g}^{-1}$ wet weight (ww) for the toxic equivalent concentration (TEQ) standardised to the 2378 tetrachlorodibenzodioxin toxicity in all fish species, except eel, for which the threshold was set at $12 \mathrm{pg} \cdot \mathrm{g}^{-1} \mathrm{ww}$. Most of the TEQ load in fish is due to dioxin-like PCBs (DL-PCBs), and is correlated with the total PCB load (Bhavsar et al., 2007a; Bhavsar et al., 2007b) or the sum of indicator congeners ( $\Sigma$ iPCB; Babut et al., 2009). Thus a $\Sigma$ iPCB load of $154 \mathrm{ng}^{-1}{ }^{-1}$ (ww,

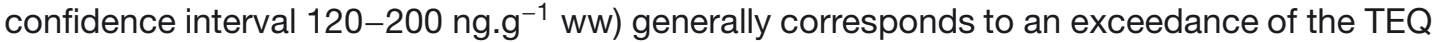
regulatory limit. The 2006 standards were revised in 2012 in two contrasted ways: (i) toxicity equivalent factors (TEF) were adjusted (Van den Berg et al., 2006), several of DL-PCB TEFs being reduced, and (ii) the thresholds were lowered to $10 \mathrm{pg} \cdot \mathrm{g}^{-1} \mathrm{ww}$ and $6.5 \mathrm{pg} \cdot \mathrm{g}^{-1} \mathrm{ww}$ for eels and other species respectively (E.C., 2011). Overall this revision yielded only minor changes in terms of regulatory limit exceedance as well as correlation to $\mathrm{\Sigma iPCB}$ (Babut et al., 2011).

Due to the number of advisories restricting freshwater fish consumption in France since 2005, a national action plan was adopted in 2008. The plan's main goals were to gain updated knowledge on the contamination levels in and pathways to (freshwater) biota, and to propose and carry out appropriate management measures. In this context, a national database on fish contamination by PCDDs and related compounds, including PCBs (DL-PCBs as well as nonDL-PCBs) was developed and published (Eaufrance). About three hundred sites have been investigated nationwide, and classified according to the regulatory limit exceedance. Further actions according to the plan could encompass source reduction, provided such sources can be identified. "Source" is considered here in an extensive meaning, not necessarily spatially determined. For instance, atmospheric deposition is a source, as well as specific PCB uses or releases at specific locations. However, as the sources are quite old, changes in source composition have probably occurred over time, potentially hampering the source identification process.

Our objective here is to conduct an exploratory study of the source pattern distribution in the national fish contamination database, so as to identify the relative contributions of typical contamination sources. Our working hypotheses are: (i) the fish contamination patterns are 


\section{Table I}

Structure-activity groups of some PCB congeners according to (Yunker et al., 2011) - in bold: congeners analysed in the present study.

\begin{tabular}{|c|c|c|c|c|}
\hline SAG & $\ln [\mathrm{Cl}]$ & $\begin{array}{l}\text { Structural features: } \\
\text { substitution pattern } \\
\text { and vicinal H atoms }\end{array}$ & Congeners & Biotransformation \\
\hline$T$ & $5-10$ & $\begin{array}{l}\text { no vicinal ortho-meta } \\
\text { nor meta-para } \\
{[\mathrm{H}] \text { atoms }}\end{array}$ & $\mid \begin{array}{c}120,133,146,153,154,155 \\
162,167,168,169,172,175 \\
178,180,182,183,184,187 \\
188,189,191,193,194,196 \\
197,198,200,201,202,203 \\
205,206,207,208,209\end{array}$ & \multirow[t]{2}{*}{$\begin{array}{c}\text { Not metabolized in } \\
\text { mammals; likely not } \\
\text { metabolized in fish (citations } \\
\text { in Yunker et al., 2011) }\end{array}$} \\
\hline II & $5-8$ & $\begin{array}{c}\text { vicinal ortho-meta }[\mathrm{H}] \\
\geqslant 2 \text { ortho }[\mathrm{Cl}]\end{array}$ & $\begin{array}{c}47,85,90,99,100,115,119 \\
128,130,137,138,139,140 \\
147,158,163,166,170,171 \\
177,190\end{array}$ & \\
\hline \multirow[t]{2}{*}{ III } & $2-4$ & $\begin{array}{c}\text { vicinal ortho-meta }[\mathrm{H}] \\
2 \text { para- }[\mathrm{Cl}]\end{array}$ & $\begin{array}{c}15,28,37,60,63,66,68,74 \\
77,81\end{array}$ & \multirow{2}{*}{\begin{tabular}{|c|} 
Metabolized in seals, partially \\
metabolized in cetaceans, \\
not metabolized in bears and otters. \\
Likely not metabolized in fish except \\
congener 77 (Buckman et al., 2007; \\
Buckman et al., 2006)
\end{tabular}} \\
\hline & $5-6$ & $\begin{array}{l}\text { vicinal ortho-meta }[\mathrm{H}] \\
2 \text { para- }[\mathrm{Cl}] \\
<2 \text { ortho }[\mathrm{Cl}]\end{array}$ & $\begin{array}{c}105,114,118,123,126,156 \\
157\end{array}$ & \\
\hline IV & $4-6$ & $\begin{array}{l}\text { vicinal meta-para }[\mathrm{H}], \\
\geqslant 2 \text { ortho }[\mathrm{Cl}]\end{array}$ & $\begin{array}{c}\mathbf{5 2}, 72,73,92, \mathbf{1 0 1}, 113,124 \\
141,164\end{array}$ & $\begin{array}{l}\text { Congeners 52, } 101 \text { selectively } \\
\text { metabolized in flounder (Elskus et al., } \\
\text { 1994); congener group metabolized in } \\
\text { rainbow trout (Buckman et al., 2007) }\end{array}$ \\
\hline $\mathbf{V}$ & $4-8$ & $\begin{array}{l}\text { vicinal meta-para }[\mathrm{H}] \\
\quad \geqslant 3 \text { ortho }[\mathrm{Cl}]\end{array}$ & $\begin{array}{c}103,135,144,149,150,151 \\
174,176,179,185,199\end{array}$ & $\begin{array}{l}\text { metabolized in rainbow trout } \\
\text { (Buckman et al., 2007) }\end{array}$ \\
\hline
\end{tabular}

related to source composition and (ii) the contamination pattern is influenced by fish exposure, feeding behaviour and metabolism.

\section{BACKGROUND}

Basically, the composition of technical mixtures is related to PCB uses. Therefore the composition patterns of current environmental mixtures might help to elucidate the origins of the present contamination. Nonetheless in practice this diagnosis is hindered by the biotransformation competencies of organisms. As this competency depends both on the organism and the congeners structural features (Boon et al., 1997; Muir, 1988), it is critical to address both aspects when analysing the congener profiles in fish.

\section{> BIOTRANSFORMATION OF PCB TECHNICAL MIXTURES IN THE ENVIRONMENT}

PCBs constitute a good model for studying the relationships between structural features and properties: they share a simple basic structure and display various combinations of congeners, with different physicochemical properties, in particular in terms of partition among media. These properties in turn determine the interactions of PCBs with biota. PCB bioaccumulation (e.g. Boon et al., 1994), binding to biological receptors (e.g. Boon et al., 1997), toxicity (Eriksson et al., 2002) or metabolism (e.g. Yunker et al., 2011) have thus been related to the number and positions of chlorine atoms on the biphenyl nucleus. Ultimately, these attempts have all looked for an ideal classification of PCB congeners into a few groups sharing the same behaviour, with respect to the property considered. Until now many studies have focussed on mammals, and fewer on fish.

These studies converged towards the definition of five groups of congeners (Table I), with respect to the type of mixed-function oxidase (MFO) activity induction and the chlorine substitution pattern (Boon et al., 1989; Boon et al., 1997; Clarke, 1986). Note that a large proportion 
of PCB congeners are not considered in this classification because they neither induce nor are metabolised by the cytochrome P450 system which supports MFO activity.

Fish have generally been considered to have a lower metabolism than mammals for most chemicals, including PCBs (Hinz and Matsumura, 1977). Congeners with adjacent meta-para un-substituted carbon atoms may selectively be biotransformed and eliminated by certain species, e.g. the winter flounder (Pseudopleuronectes americanus; Elskus et al., 1994), the rainbow trout (Oncorhynchus mykiss; Wong et al., 2002) or the lake trout (Salvelinus namaycush; Wong et al., 2004). Highly chlorinated congeners with no meta-para un-substituted carbon atoms may be hydroxylated, to a limited extent (Buckman et al., 2006; Li et al., 2003). In a laboratory study encompassing a range of 92 congeners in rainbow trout, congeners having vicinal meta-para $\mathrm{H}$ atoms were metabolised at temperatures of $12{ }^{\circ} \mathrm{C}$ or higher, while no biotransformation occurred for congeners with either ortho-meta $\mathrm{H}$ atoms or no vicinal $\mathrm{H}$ atoms at all (Buckman et al., 2007). These observations made it possible to set structureactivity relationships and group congeners according to their ability to biotransform, first for 11 congeners (Boon et al., 1997), and more recently to a more complete set of congeners (Yunker et al., 2011). Table I summarises the characteristics of five structure-activity groups (SAG) according to Yunker et al. (2011). The latter paper also mentions a group VI composed of the remaining PCB congeners, with no distinct structural pattern.

\section{> PATTERN ANALYSIS}

Identifying patterns in datasets involving many variables is a recurrent issue in natural / environmental sciences, usually tackled by factorial analysis on proportions of each variable or group of variables. This minimizes the influence of the magnitude of variable values, but may lead to a closure effect (Johansson et al., 1984), as by construction all the sums of variables equal to 1 . This could generate spurious negative correlations between major variables as well as positive correlations between minor variables. The development of multivariate statistics, such as principal component analysis (PCA) reduces the number of variables and identifies patterns in the data, while reducing the closure effect provided the variables are scaled centred. Alternatively the analysis could be performed on log-transformed proportions (Howel, 2007). However, all these approaches are not applicable to data sets with values below the limit of quantification (LQ). Moreover the negative eigenvectors sometimes obtained in PCA are not appropriate when looking for source profiles.

While there are numerous examples of pattern analysis using models adapted from multivariate statistics in environmental matrices such as air (Logue et al., 2009; Pekney et al., 2006), soil (Skrbic and Durisic-Mladenovic, 2007) or bottom sediment (Bzdusek et al., 2006a; Bzdusek et al., 2006b; Du et al., 2008), there have been fewer attempts to develop this kind of approach on biota. Examples include an exploration of spatial differences in organochlorine chemical loads in herring gull colonies of the Great Lakes (MacDonald et al., 1992), a study of PCB accumulation features, but neither spatial nor source pattern analysis in the Baltic Sea area (Falandysz et al., 2002), an attempt to differentiate local PCB sources in the Hudson River and its estuary (Ashley et al., 2003; Monosson et al., 2003), and a study of PCB pattern variations across species, trophic levels, and wild versus farmed salmon (Yunker et al., 2011).

\section{MATERIALS AND METHODS}

\section{> SAMPLING SITES}

Three hundred and thirteen sites, i.e. about hundred sites per year, were selected throughout the main French catchments, in consultation with respective water agencies. For the first 2 years the selection was based on PCB contamination in sediments as determined from past monitoring records at sites where fish populations were regularly monitored, or downstream of large cities, or in reaches granted to professional fisheries. A few sites were located in coastal lagoons or estuaries, meaning that sea fish samples are recorded in the database, along with freshwater species samples. 


\section{> SAMPLING AND ANALYSIS}

Fish were caught in low-flow periods (June to October) from 2008 to 2010 by electro-fishing by the French national agency for water and aquatic environments (Onema) using a standard protocol. According to the data collected prior to 2008 and analysed by AFSSA (2008), the most common French freshwater species were classified into two groups, one of species displaying high PCB contents, and thus called "prone to accumulate PCBs" (group A) and one of less impacted species (group B). Species in group A tend to stay at the bottom and feed primarily on benthos, while species from group B are pelagic or live at the bottom, with a more diverse diet (Table EM-I in the supporting electronic-only material). This classification was a structuring component of the monitoring strategy developed since 2008 in order to establish a nationwide diagnosis of fish contamination. The recommendation was to catch five samples of each group at each sampling site. Fillets were cut and frozen by ADIV (French technical institute for meat products, Clermont-Ferrand, France), then transferred to LABERCA (national reference laboratory for dioxins, and PCBs, either DL or non DL, Nantes) where they were freeze-dried. Eighteen PCB congeners i.e. six indicators $(28,52,101,138$, 153 and 180) and 12 dioxin-like congeners (DL-PCB; 77, 81, 105, 114, 118, 123, 126, 156, $157,167,169$ and 189) were analysed according to the European guidelines for the official control of dioxins and the determination of DL-PCBs in food (E.C., 2002). The extraction was performed in a Dionex ASE 300 device with toluene/acetone, 70:30 (v/v) mixture. Purification and fractionation encompassed three successive steps, using silica, Florisil and celite/carbon columns. Separation of coplanar PCBs from non-planar PCBs was achieved on an activated mixture of Florisil/Carbopack C/Celite 545. Analysis was performed by gas chromatography coupled with high-resolution mass spectrometry (HR-GC-MS; HP 6890 GC coupled with JMS $700 \mathrm{D}$, Jeol). Chromatographic separations were achieved on a DB-5MS column. The laboratory used surrogates $\left({ }^{13} \mathrm{C} 12-1,2,3,4-\mathrm{TCDD}\right.$ for the PCDD/Fs, ${ }^{13} \mathrm{C} 12-\mathrm{PCB} 111$ for PCBs) to check for analytical recoveries. The limit of quantification (LQ) ranged from 0.02 to $8 \mathrm{pg} \cdot \mathrm{g}^{-1}$ wet weight (WW) for PCBs, and the mean analytical uncertainty was about $20 \%$. The results were then transferred to an online database (http://www.pollutions.eaufrance.fr/pcb/donnees. html).

\section{> DATABASE DESCRIPTION}

A total of 2848 fish samples from 313 sites and 36 fish species are recorded in the database. The variables recorded include a few biometric characteristics (fish size, weight, but neither age nor gender in most cases) as well as lipid content, moisture, PCB, PCDD and PCDF congener concentrations and toxic equivalent concentrations (TEQ). The latter variable is calculated on the basis of 1998 toxic equivalent factors (TEFs) (Van Den Berg et al., 1998).

\section{$>$ DATA SELECTION}

Given that not all the data recorded are relevant, a rigorous selection has to be performed prior to statistical analysis. The selection procedure, summarised in Figure 1, was adapted from a previous study on another database (Babut et al., 2012). Records where the species name was inadequately reported (incomplete or ambiguous) were discarded first. Secondly, as many samples consisted of pools of fishes of different sizes, all the pools were discarded so as to keep only samples from one individual. Then species rarely found were also removed: only species for which 20 samples or more were available were kept, making a final dataset of 1259 samples of 15 species, from 259 sites. This selection had to be further refined for the ANCOVA, as the qualitative variable (propensity to accumulate PCBs) was not documented for trout and mullet, and the size was not available for a few records. The resulting dataset included 1181 records from 13 species, collected at 245 sites. Another two-stage selection step was also introduced for principal component analysis (PCA), i.e. removal of mullets (first 


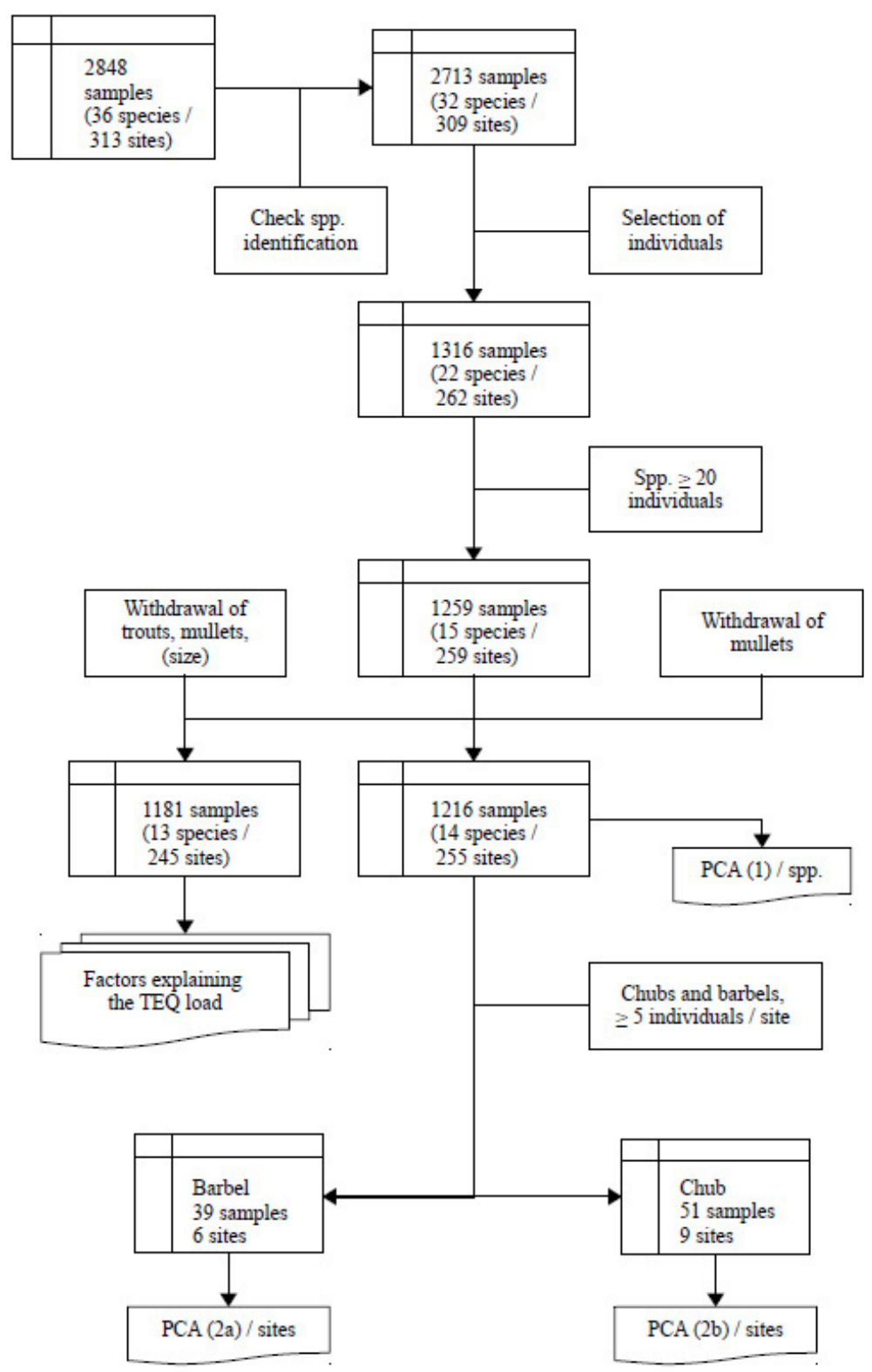

Figure 1

Data selection and processing flow-chart.

stage, 1216 samples from 14 species, 255 sites), then species, where at least five specimens per site were required. This resulted in a set of 39 barbel samples covering six sites and another set of 51 chub samples covering nine sites.

\section{> STATISTICS}

All the statistics were realised with $R$ software ( $R$ Development Core Team, 2010). We used an analysis of covariance (ANCOVA) to study the overall relationships between fish contamination and their characteristics. ANCOVA is a variation of the generalised linear model (GLM) approach, and is typically used to account for covariates when comparing contaminant-specific situations between sites (e.g. Butt et al., 2008).

The contamination profiles were studied using PCA, based on the proportions of groups of congeners using structure-activity groups (SAG) as described in Table I. These proportions 
were calculated as the ratio of the sum of congener concentrations in the respective groups and the sum of the concentrations of the eighteen measured congeners, then scaled-centred. The results of the PCA were assessed by factor discriminant analysis (FDA), a factor analysis based on intra-class variances, making it possible to test the a priori assignment of individuals (i.e. samples) to a group or a class (in this case patterns identified in the PCA).

\section{RESULTS}

\section{> OVERVIEW OF THE FISH CONTAMINATION DATA - TEQ LOAD}

Overall, eels (Anguilla anguilla), barbels (Barbus barbus), common and silver breams (Abramis brama and Blicca bjoerkna respectively), and common carps (Cyprinus carpio) display TEQ median values above the regulatory thresholds of 12 and $8 \mathrm{pg} \cdot \mathrm{g}^{-1} \mathrm{ww}$. Chubs (Squalius cephalus), crucian carps (Carassius carassius), pike-perches (Sander lucioperca), and giant catfishes (Silurus glanis) have TEQ median values below the regulatory threshold, but a part of their respective distributions still exceeds the threshold. Pikes (Esox lucius) and nases (Chondrostoma nasus) are systematically below. Nevertheless these differences are not only due to inter-species differences of bioaccumulation, but also at least partially to inter-site variations, i.e. the species are not evenly distributed among sites.

An ANCOVA was performed on the whole data set with the category, as defined by AFSSA (2008), fish size as predictors, and TEQ as the explained variable. Fish size was expected to influence PCB accumulation as a long-term consequence of differential rates of uptake and elimination (Clark et al., 1990). All variables were log-transformed. "Category" refers to the propensity of fish species to accumulate hydrophobic contaminants, in particular PCBs, dioxins and furans, and reflects species ecological traits, namely their position in the river and feeding behaviour (Table EM-I in electronic-only material).

The assumptions of normality and homogeneity of residuals were met. The relationships between the log TEQ and the log size or category were highly significant $p<2.2 e^{-16}$ in both cases). The slopes and intercepts of the regression line between $\log T E Q$ and log Size differ in both categories $\left(p<1.08 \mathrm{e}^{-8}\right.$; equation (1) for the species prone to accumulating PCBs, including eels; equation (2) for the group of species less prone to accumulating PCBs).

$$
\begin{gathered}
\log T E Q=1.8341( \pm 0.1748)^{*} \log \text { Size }-4.0015( \pm 0.4812) \\
\log T E Q=0.1847( \pm 0.2292)^{*} \log \text { Size }-0.2064( \pm 0.598) .
\end{gathered}
$$

Another ANCOVA was also performed on the whole dataset, with the lipid content and category as predictors and TEQ as the explained variable. In this case also, the relationships between the log TEQ and the log lipid content or category were highly significant $\left(R^{2}=0.61\right.$, $\left.p<2.2 \mathrm{e}^{-16}\right)$, but the assumptions of normality and homogeneity of residuals were violated. When eels $(N=368)$ are removed from the dataset, $R^{2}$ falls down to 0.14 for the relationships between log TEQ, log Size and category. In this case, type I error rate (false positives) amounts $4.55 \%$, while type II (false negatives) reaches $14.76 \%$.

The predictive ability of these two models is nevertheless limited for some species (Table II): while overall $75 \%$ of the samples are correctly predicted, this proportion falls to $50 \%$ or less for the barbel; the silver bream, and the giant catfish. Moreover, the same species, as well as the two bream species, the carp and the tench, display rather high type II error rates (falsenegatives). These drawbacks may be explained (i) by the limited number of samples for some species; and (ii) by the uneven spatial distribution of fish species among the sites studied. The magnitude of contamination of the sites where fishes were caught is not accounted for in the models. If, for instance, large size giant catfish specimens were caught at "clean" sites, they would be predicted to exceed the guideline, according to their size, while they would not have been exposed.

In summary, fish species ecological traits (position in the river, feeding behaviour), as summarised in the abovementioned two categories are an important factor for explaining PCB 


\section{Table II}

Performance of equations (1) and (2) for predicting exceedance of the regulatory thresholds; $A=$ species prone to accumulate $P C B$, equation (1); $B$ = species less impacted, equation (2).

\begin{tabular}{|c|c|c|c|c|c|c|c|c|c|c|c|c|c|}
\hline & \$ & 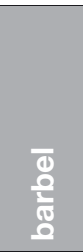 & 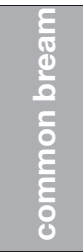 & $\begin{array}{l}\frac{5}{10} \\
\frac{10}{0} \\
\frac{0}{0} \\
\frac{2}{\omega}\end{array}$ & $\frac{2}{\frac{2}{80}}$ & 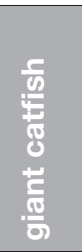 & $\begin{array}{l}\frac{2}{10} \\
\frac{8}{80} \\
\frac{10}{10} \\
\frac{10}{3} \\
\frac{2}{3}\end{array}$ & $\frac{0}{2}$ & $\frac{\circ}{\frac{0}{2}}$ & $\begin{array}{l}\frac{c}{0} \\
\text { ¿ू } \\
0\end{array}$ & 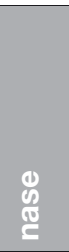 & $\begin{array}{l}\frac{}{0} \\
\frac{0}{0} \\
\frac{0}{1} \\
\frac{1}{2} \\
\frac{2}{2}\end{array}$ & $\begin{array}{l}\frac{-5}{0} \\
\frac{c}{9} \\
\end{array}$ \\
\hline Category & $A$ & $A$ & $A$ & $A$ & $A$ & $A$ & $B$ & $B$ & $B$ & $B$ & $\mathrm{~B}$ & $B$ & $\mathrm{~B}$ \\
\hline $\mathbf{N}$ & 368 & 131 & 72 & 40 & 35 & 46 & 33 & 22 & 269 & 62 & 27 & 48 & 28 \\
\hline $\begin{array}{l}\text { \% samples } \\
\text { correctly } \\
\text { predicted }\end{array}$ & 75.3 & 47.3 & 69.4 & 50 & 62.9 & 19.6 & 90.9 & 100 & 90.3 & 77.4 & 100 & 89.6 & 78.6 \\
\hline \% type II & 3.3 & 16 & 22.2 & 50 & 22.9 & 0 & 9.1 & 0 & 9.7 & 22.6 & 0 & 10.4 & 21.4 \\
\hline
\end{tabular}

bioaccumulation. Fish size, which is a proxy for fish age, is another important factor, and cannot be dissociated from the former. Lipid content is also an influencing factor, whose relationship to other factors remains uncertain.

\section{>ACCUMULATION PATTERNS BY SPECIES}

A first PCA was performed on the whole set of individuals in order to analyse the interaction between species and PCB congener profiles. PCB congeners were considered as SAG groups, as summarised in Table (Yunker et al., 2011). Group III was sub-divided in two groups, according to the number of chlorine atoms on the biphenyl backbone (Yunker et al., 2011): group III-[2-4] included congeners 28, 77 and 81, while group III-[5-6] included congeners 105, 114, 118, 123, 126, 156 and 157.

As the first two components support $78 \%$ of the variability $(57 \%$ for the first principal component [F1] and $21 \%$ for the second [F2], we focussed the analysis on the $F 1^{\star} F 2$ plane. All SAGs contribute to $\mathrm{F} 1$, to various extents (from $30 \%$ for groups I and IV to $11-15 \%$ for the others) while the main contributions to F2 came from groups II and III [5-6]. On F1, SAGs I-II display negative coordinates while III-IV display positive ones (Figure 2).

The projection of species on the $\mathrm{F} 1{ }^{*} \mathrm{~F} 2$ plane shows different patterns in accumulation of SAG groups (Figure 2): compared to other species, barbels and giant catfishes are mainly characterised by SAG I and II congeners. On the other hand, river trouts (Salmo trutta fario) display higher proportions of SAG IV, i.e. less chlorinated congeners. Common carps and nases have a higher proportion of SAG III-[2-4], while eels accumulate more a mixture of SAG II and III[5-6]. Interestingly, the propensity to accumulate PCBs does not appear as such in the distribution of species on the $\mathrm{F} 1^{\star} \mathrm{F} 2$ plane: species belonging to different accumulation propensity groups, such as roach and breams, or nase and common carp, have close coordinates, while barbel, one of the most typical accumulating species, displays a very different position on the plane from the position of eel, another typical accumulating species.

The congener pattern displayed by any individual fish of any species at a given time is the outcome of several conditions: exposure to PCB sources, physicochemical properties of PCB congeners, species traits, in particular feeding behaviour, and physiology (biotransformation, excretion). At the spatial scale of this analysis, the interspecies variability of species traits and metabolism plays a prominent role and conceals the sources' variability. As a consequence, spatial contamination patterns have to be studied in (a subset of) species showing distinct accumulation behaviour. We selected the barbel and the chub, which are the most widespread species in the database. 


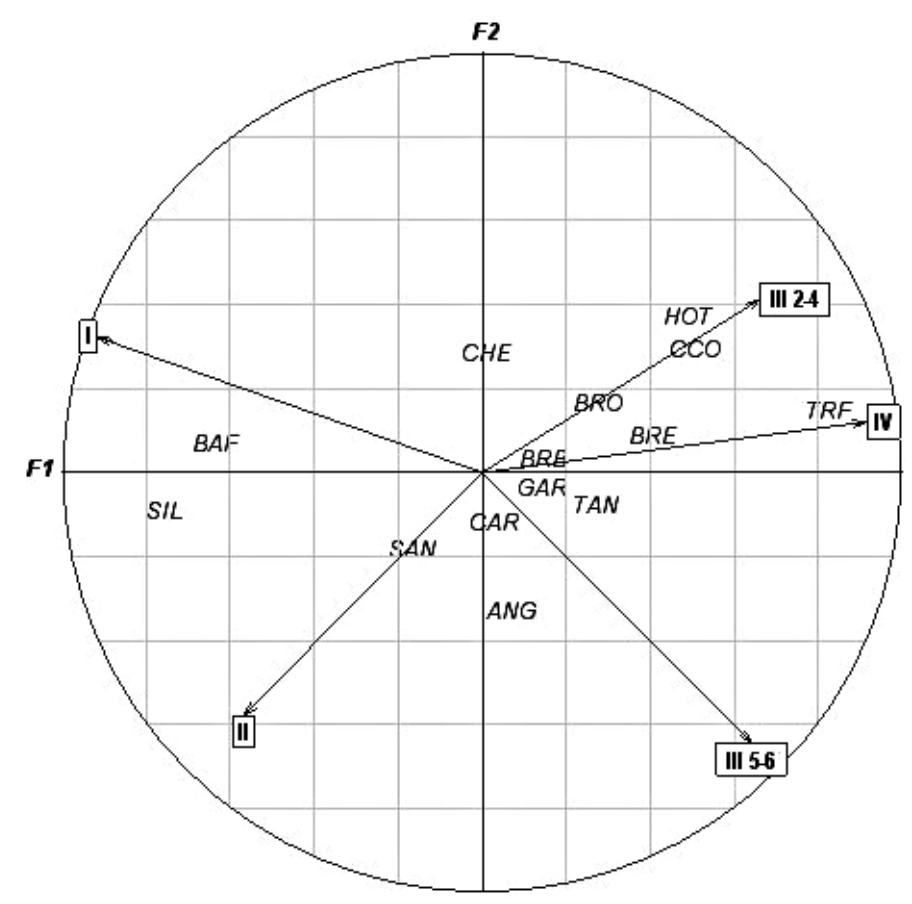

\section{Figure 2}

Projection of fish species on the PCA(1) F1*F2 plane (ANG: eel; BAF: barbel; BRB: silver bream; BRE: common bream; BRO: pike; CAR: crucian carp; CCO: common carp; CHE: chub; GAR: roach; HOT: nase; SAN: pike-perch; SIL: giant catfish; TAN: tench; TRF: river trout).

\section{> AN APPROACH TO SPATIAL PATTERNS}

Two data subsets were extracted from the database, in order to detect spatial differences: we looked for sites having at least five samples of either barbel or chub, yielding 39 samples from six sites for the barbel, and 51 samples from nine sites for the chub (Figure 1). Two PCAs were then performed on these subsets. The variability explained by the first two components (F1-F2) was $86 \%$ for the barbel and $80 \%$ for the chub. Again, the part of this variability supported by the third principal component (F3) was limited (12 and 10\% respectively) so we focussed the analysis on the $\mathrm{F} 1{ }^{\star} \mathrm{F} 2$ plane for both species. In the barbel PCA, F1 is explained mainly by SAGs I (33\%), III [5-6] (22\%), IV (24\%), and to a lesser extent by SAG III [2-4] (17\%). F2 is mostly explained by SAG II (44\%) and III [2-4] (26\%). A similar pattern was obtained in the chub PCA, where F1 was mainly explained by SAGs I (33\%), III [2-4] (27\%), IV (29\%). So the main difference with barbel relative to this first component is the very low contribution of SAG III [5-6]. For F2 the main contributions in the chub PCA were from SAG II (30\%) and III [5-6] (60\%).

Congener patterns differ among sites for both species (Figure EM-1 in the electronic material). In the chub PCA (F1*F2 plane), site 02089900 (Orne River at Richemont) has a distinct position along the F1 axis, with a higher proportion of SAG I and less SAG II and IV (Figure 3). Moreover, sites 02001048 (Rhine River at Biesheim), 02103850 (Bist River at Creutzwald) and 02038150 (III River at Offendorf) display close coordinates on the plane. Not only the barycentres of individual groups have close coordinates, but also the individuals of these sites are well grouped on the $\mathrm{F} 1^{\star} \mathrm{F} 2$ plane. This profile is characterised by higher proportions of SAG II and IV, and accordingly a lower proportion of SAG I. The third typical profile corresponds to the site 04088000 (river Furan at Andrezieux-Boutheon), which essentially displays an increased proportion of SAG III [5-6]. Other sites are less distinctly grouped in the middle of the plane.

In the barbel PCA F1 ${ }^{\star}$ F2 plane, site 03004095 (Seine River at Bourguignons), where no individual fish exceeds the regulatory threshold, shows a higher proportion of SAG I congeners, 

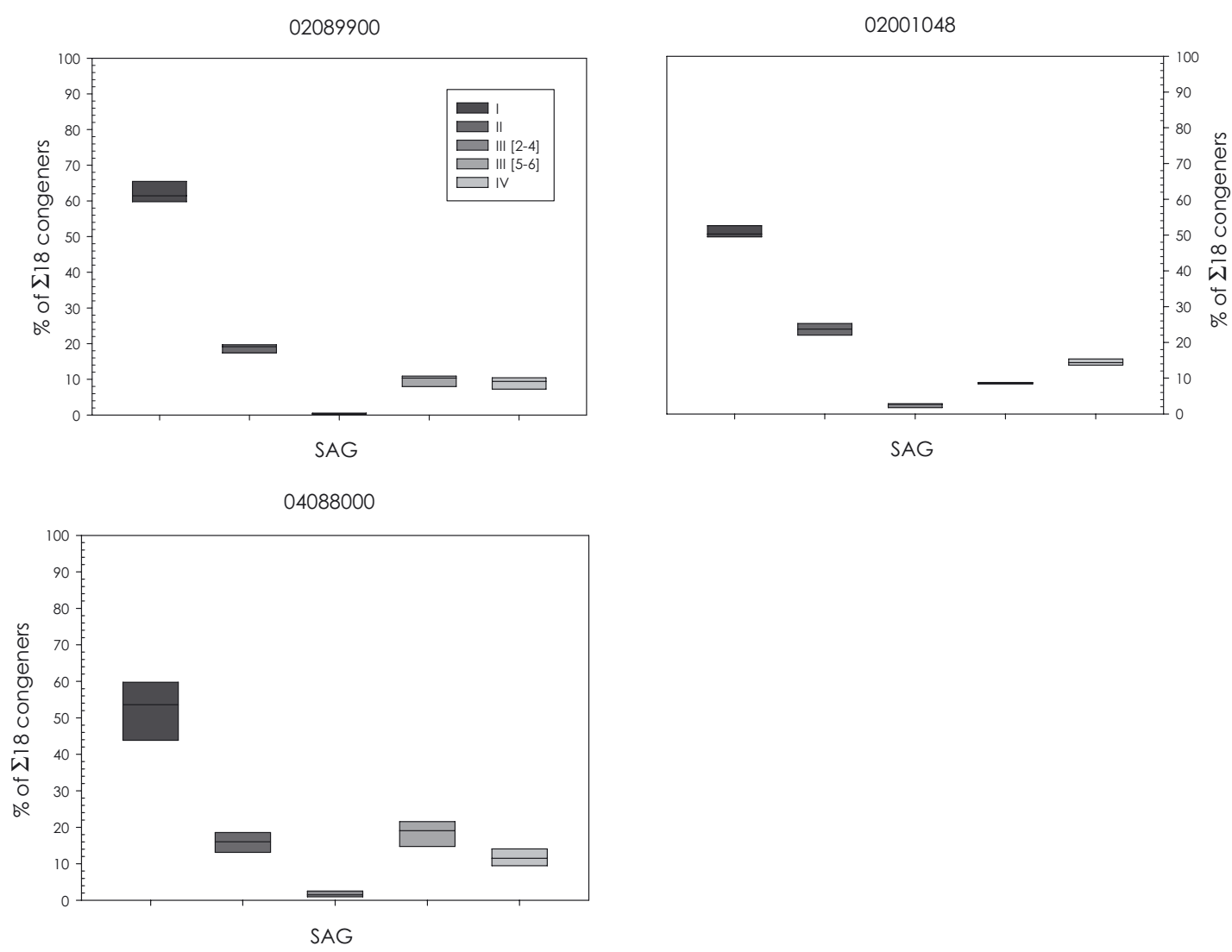

Figure 3

Typical profiles for the chub.

in contrast with site 06070100 (Fier River at Poisy) where SAG IV and III [2-4] proportions are higher (Figure 4). Site 02055000 (Moselle River at Bainville) differs from site 03004095 essentially by a slightly higher proportion of SAG II congeners. The other sites, such as 04088000 (Furan River at Andrezieux-Boutheon) are close to the intersection of the F1 and F2 axes.

We assume that the sites occupying remote positions on the $\mathrm{F}^{*} \mathrm{~F} 2$ planes in both PCAs represent distinct patterns, while those in the central part of the planes display mixed patterns or intermediate stages between the former patterns. This leads us to consider that barbels support four distinct patterns (C, D, E, F, Table III), and one intermediate profile (G). Chubs are characterized by three patterns $(B, C, A$, Table III) and two intermediate profiles $(H, I)$. More details are provided in the electronic-only material (Figures EM-1 ad EM-2, Table EM-II).

Interestingly, the proportions of SAG III (2-4) and IV decrease from pattern D to F for the barbel and from $B$ to $A$ for the chub (Table III). Two FDAs were then made with patterns as the qualitative variables ( $D$ to $F$, and $G$ for the barbel; $A$ to $C$, plus $H$ and I for the chub), and SAG proportions as the quantitative explanatory variables. Overall, $87.2 \%$ of the barbels were correctly classified, and $94.1 \%$ of the chubs (Table EM-III in the electronic-only material). Four barbel individuals out of 39 were incorrectly classified: two were assigned a priori to group $\mathrm{C}$ but are classified in group $E$ by the FDA, one was assigned to group $E$ and was actually in group $\mathrm{C}$, and the last was assigned to group $\mathrm{D}$ and was in fact in group $\mathrm{C}$. All these groups are close to one another in the PCA and somewhat overlap (Figure EM-1 in electronic-only material). Three chub individuals out of 51 were incorrectly classified: one assigned to group $\mathrm{C}$ was actually in group $\mathrm{H}$, one assigned to group $\mathrm{H}$ was in group $\mathrm{A}$, as well as one assigned to I. As for barbel, these groups are close to one another in the PCA and overlap. 

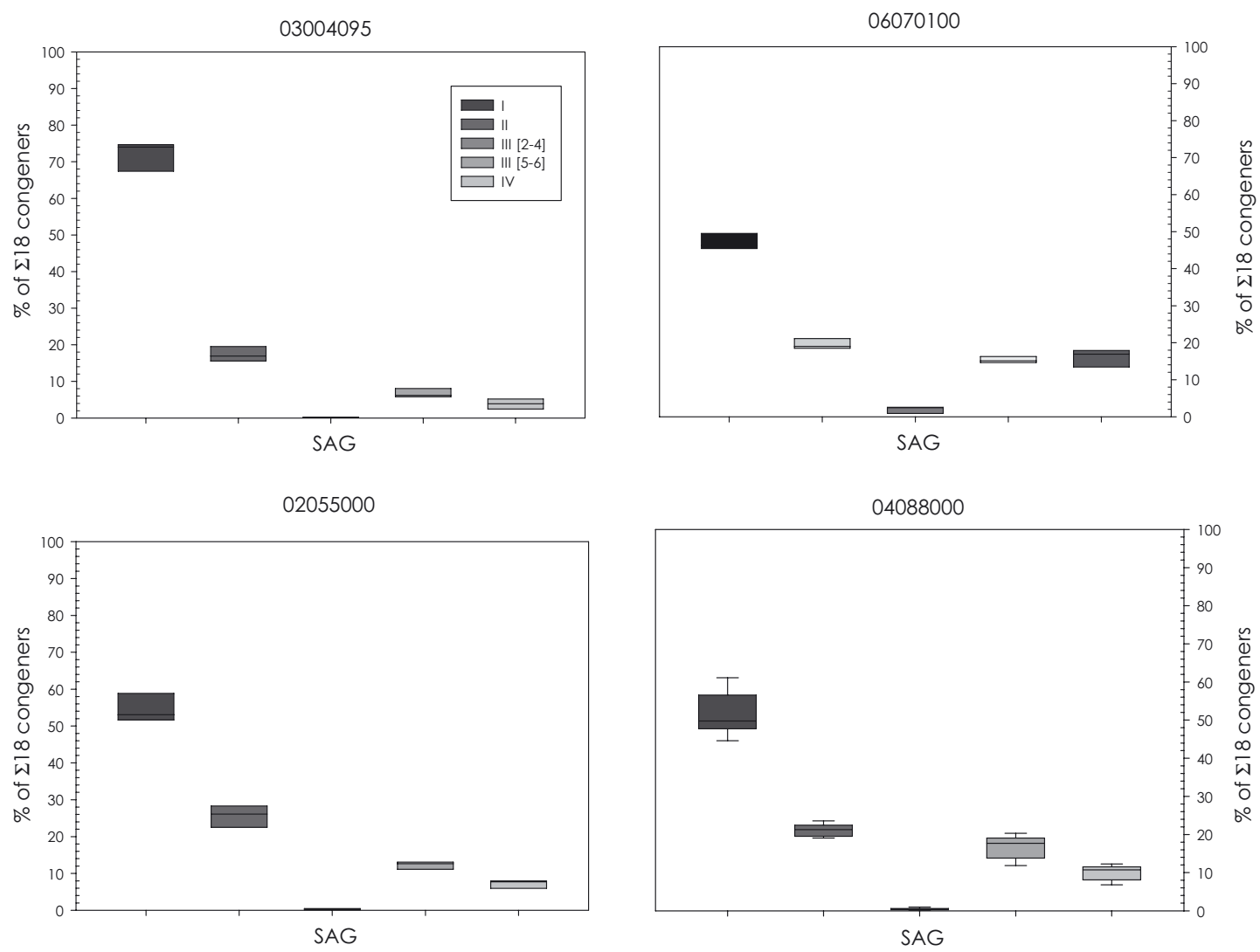

Figure 4

Typical profiles for the barbel.

\section{DISCUSSION}

Grouping fish species according to their propensity to accumulate PCBs performed quite well for assessing the potential for exceedance of the regulatory limit for fish consumption. The models obtained from ANCOVA (Eqs. (1) and (2)) should not be used in a predictive way, because (i) predictions were not consistent for some species, due to the low number of samples, (ii) the site selection was biased towards contamination, and (iii) the dataset was not well balanced among species. Eels' weight in the ANCOVA was probably too important. Nevertheless, our goal here was not to develop a model allowing to predict regulatory limit exceedance, but to check the validity of the distinction between categories A and B made in the sampling strategy. Fish size would thus not be a good predictor of contamination at all sites. The two groups rely on ecological traits (position in the water column, feeding behaviour) rather than physiological factors, though the lipid content was also quite influential.

Predator species such as pike were not expected to appear in group B; pike is known to biomagnify highly chlorinated PCB congeners (Looser and Balschmiter, 1998). In their study of the Severn estuary, Harrad and Smith (1998) also showed rather elevated concentrations of PCBs in pikes, though lower than in eels by a factor of 5 to about 10 for the most chlorinated congeners. The classification of pike in group $B$ is therefore not inconsistent with previously reported results, but remains somewhat surprising, when compared for example to roach, which is not known to biomagnify PCBs (Looser and Balschmiter, 1998). Several factors may explain AFSSA's statement about pike (AFSSA, 2008): first, the exposure conditions may have changed during the two decades since these publications, as a consequence of prohibition measures among others. Second, pikes are sometimes raised in fish-farms and introduced into rivers by local fishing groups; these manipulated fishes would not accumulate PCBs to 


\section{Table III}

Summary of potential sources and typical SAG profiles.

\begin{tabular}{|c|c|c|c|c|}
\hline $\begin{array}{l}\text { Proffle } \\
\text { type }\end{array}$ & $\begin{array}{c}\text { Site } \\
\text { (species) }\end{array}$ & SAGS & $\begin{array}{l}\text { Median (min-max) } \\
\text { proportion }\end{array}$ & $\begin{array}{l}\text { Potential } \\
\text { sources }\end{array}$ \\
\hline A & 02089900 (chub) & $\begin{array}{l}\text { I } \\
\text { II } \\
\text { III [2-4] } \\
\text { III [5-6] } \\
\text { IV }\end{array}$ & $\begin{array}{c}61.4(59.6-66.4) \\
19.2(16.7-20.1) \\
0.4(0.2-0.6) \\
10.3(7.5-11.3) \\
9.4(6.9-11.2)\end{array}$ & $\begin{array}{l}\text { Wire-drawing mill, } \\
\text { electricity power station. } \\
\text { Possibly production } \\
\text { of transformers. }\end{array}$ \\
\hline B & $\begin{array}{c}02001048,02038150, \\
02103850 \text { (chub) }\end{array}$ & $\begin{array}{l} \\
\text { II } \\
\text { III [2-4] } \\
\text { III [5-6] } \\
\text { IV }\end{array}$ & $\begin{array}{c}50.3(49.3-53.4) \\
23.7(21.4-25.5) \\
2.7(1.4-2.9) \\
8.6(8.3-8.8) \\
14.4(13.3-15.4)\end{array}$ & $\begin{array}{l}\text { Industrial waste dump, } \\
\text { maintenance of electrical } \\
\text { devices (transformers, } \\
\text { coils), coal mine... }\end{array}$ \\
\hline $\mathbf{C}$ & 04088000 (chub) & $\begin{array}{l} \\
\text { II } \\
\text { III [2-4] } \\
\text { III [5-6] } \\
\text { IV }\end{array}$ & $\begin{array}{c}53.6(42.4-61.8) \\
16.1(11.4-19.8) \\
1.5(0.7-3.2)) \\
19.1(14.0-21.8) \\
11.5(8.4-15.3\end{array}$ & Hardware, steelwork. \\
\hline $\mathbf{D}$ & 06070100 (barbel) & $\begin{array}{l} \\
\text { II } \\
\text { III [2-4] } \\
\text { III [5-6] } \\
\text { IV }\end{array}$ & $\begin{array}{c}46.2(44.9-50.7) \\
19.0(18.3-22.4) \\
2.4(0.5-2.7) \\
15.1(14.5-16.4) \\
16.9(12.6-18.4)\end{array}$ & Metals recycling \\
\hline$E$ & 02055000 (barbel) & $\begin{array}{l} \\
\text { II } \\
\text { III [2-4] } \\
\text { III [5-6] } \\
\text { IV }\end{array}$ & $\begin{array}{c}53.1(51.5-64.5) \\
26.1(19.9-29.0) \\
0.3(0.1-0.5) \\
12.6(9.7-13.1) \\
7.7(5.8-8.1)\end{array}$ & $\begin{array}{l}\text { Transformer leak } \\
\text { (spinning mill) }\end{array}$ \\
\hline $\mathbf{F}$ & 03004095 (barbel) & $\begin{array}{l} \\
\text { II } \\
\text { III [2-4] } \\
\text { III [5-6] } \\
\text { IV }\end{array}$ & $\begin{array}{c}74.0(65.3-74.8) \\
16.9(16.8-20.4) \\
0.1(0.0-0.2) \\
6.2(6.2-8.7) \\
3.9(2.1-5.5)\end{array}$ & $\begin{array}{l}\text { No source identified } \\
\text { in BASOL }\end{array}$ \\
\hline
\end{tabular}

the same extent as native specimens, because a part of their growth occurred in fish farms, presumably preserved from exposure to PCBs. Third, the pike specimens analysed used to be rather young (Babut et al., 2011), and may accordingly have had a lower level of accumulated PCBs than other species exposed for longer periods.

Indeed, the species projection on the PCA F1*F2 plane (Figure 2) is not primarily structured according to the propensity to accumulate PCBs. Nonetheless, compared to other species the eel and the barbel, which are also the species displaying the highest PCB loads, are characterised by higher proportions of SAG II congeners, along with SAG I for the barbel and SAG III [5-6] for the eel. These groups are less metabolised and excreted than SAG III [2-4] and IV. Other species from category $A$ such as the common bream or the common carp occupy different positions on the F1*F2 plane, with higher proportions of SAG III [2-4] or IV than eels or barbels. The congener patterns of species may be influenced by several factors, such as physiology, in particular excretion functions, metabolism, and ecological traits, notably the food sources foraged. The role of physiology and metabolism may be advocated for the relative position of the river trout on the $\mathrm{F} 1{ }^{\star} \mathrm{F} 2$ plane, close to the SAG IV eigenvector, as this group include congeners metabolised by species such as rainbow trout (Table I). The lighter congeners in SAG III (i.e. SAG III [2-4]), which are partially metabolised, are more represented in nase and common carp. Common carps and river trouts do not occupy the same position in the river and have different feeding behaviours, suggesting that physiology and metabolism are more concerned by the relative positions of these species on the plane. Conversely, eel and common bream, which occupy similar positions in the river and both feed on benthic organisms have quite different coordinates on the $\mathrm{F} 1^{\star} \mathrm{F} 2$ plane. Fish species position in the 
river and feeding behaviour play a prominent role in exposure conditions and thus participate in the congener profiles observed, but we argue that this role is less important than fish physiology and metabolism.

Nonetheless, the profile observed in river trout can also be related to its higher position in catchments, that is in areas subject to deposition of lighter congeners originating from atmospheric transport.

While making it possible to study a large dataset including many variables, PCA is not devoid of drawbacks when it comes to pattern analysis. One of them is the risk of closure, which yields spurious correlations (Johansson et al., 1984). Differences in absolute concentrations among samples may also mask pattern differences. This effect can be reduced by normalizing concentrations to the sum of all quantified congeners (e.g. (Monosson et al., 2003), but this typically produces closure. Log-transformation of the normalized variables, which is sometimes proposed as a correction of this bias, does not remove the closure problem (Yunker et al., 2011). That is why these authors used a centred logratio transformation. We instead used scale-centred proportions, which in principle remove the concentration effect and prevents the risk of closure. This transformation appears simpler than the data pre-processing approach applied by (Yunker et al., 2011), while being roughly equivalent.

As the PCB hepatic biotransformation process is mostly performed by inducible enzymes (Boon et al., 1997), one might argue that congener patterns are concentration-dependent. Analysing congener patterns on the basis of proportions could accordingly be somewhat biased. In the PCA performed on species, a concentration dependency effect would increase the dispersion of individuals around respective barycentres, but not change the distribution of the barycentres on the $\mathrm{F} 1{ }^{*} \mathrm{~F} 2$ plane. In the PCAs on barbel or chub, it is expected that individuals caught at the same site have roughly identical exposure conditions, and therefore the concentration-dependency effect can be disregarded. Another possible drawback in our study relates to the unbalanced number of quantified congeners among SAG groups: five congeners in SAG I, only one in SAG II, nine in SAG III (two in the sub-group 2-4, seven in the sub-group 5-6), two in SAG IV and zero in SAG V. Nevertheless the congeners usually displaying the highest proportions, which are the indicator congeners $(28,52,101,118,138$, 153 and 180), are distributed over SAGs I to IV, while other congeners display much lower proportions. With two indicator congeners having high proportions in most samples, SAG I could nevertheless be suspected of having too much weight compared to other groups, which does not seem the case, as other SAGs have comparable correlation coefficients to principal components (PC) 1 or 2.

According to the French government online database on polluted sites (BASOL; (MEDDTL, 2012), several polluted sites are recorded upstream of some of the sites highlighted in the second PCA. For instance, a metals recycler at Cran-Gevrier is located upstream of site 06070100 (Figure 4), while a former wire-drawing mill and an electricity power station operated in the past on the Orne River and could be related to site 02089900 (Figure 3). PCB soil contamination has been recorded in BASOL for these industrial companies and could therefore be advocated as sources of fish contamination. In the case of site 02089900, however, there are two other potential sources, i.e. two sites producing electric transformers and connected to the Moselle River. As the sampling site 02089900 is located rather close to the confluence of the Moselle and the Orne rivers, fish caught there could easily move and feed in both rivers. Similarly site 04088000 is very close to a former hardware and steelworks platform. Despite this proximity, the TEQ loads observed in 2010 are all below the regulatory threshold, consistent with the conclusions recorded in BASOL, which indicate that the site has been remediated. In some other cases, the sources are less obvious. For instance, the site 02055000 is located about $20 \mathrm{~km}$ downstream of a former spinning mill, recorded in BASOL, because a leak in a transformer was detected after the site closedown. Similarly site 02001048 is located on the Rhine River, several tens kilometres downstream of the Mulhouse area, where several polluted sites are recorded in BASOL, including an illegal industrial waste dump site and a former plant involved in the maintenance of electrical devices, such as coils and transformers. Conversely, there is no record in BASOL for the area upstream of 
sites 02038150 and 02103850 . Nevertheless the latter is located in a catchment known for coal mines, which were closed in 2007. Site 02038150 is downstream of Strasbourg and its suburbs, where there are many potential sources, just as in most cities. These findings are summarised in Table III. Note that only site 04088000 was common to both PCAs; the respective profiles for chubs and barbels are rather similar (Figures 3 and 4), with in particular a higher proportion of SAGI than SAGII and SAGIII [2-4].

The differences among these profiles are not easily explained by the composition of technical mixtures historically used in the industrial processes: types $A, B$ and probably $C$ profiles correspond to an array of uses, involving various technical mixtures. If the suggested source of contamination for the barbels caught at site 06070100 was confirmed, type D would also correspond to a mixture of technical products used in former electrical devices and improperly disposed of during the metal recycling process. The only type possibly corresponding to a "pure" source is type E. Considering that SAG I and II congeners are virtually not metabolised in fish (Table I), the differences among these profiles are mainly due to SAG IV and III [2-4], suggesting that these types represent different stages of original contamination patterns over time. In this perspective, types $D$ and $E$ represent more recent sources than types $C$ and $F$ for the barbel. Similarly, types B and I are less evolved types than type A for the chub (Table EM-II and Figure EM-2 in the electronic-only material). The profile observed in barbels at site 03004095 (type F) could thus indicate the ultimate stage of this evolution, with the lowest proportions of SAG III [2-4] and IV congeners throughout the samples processed in these PCAs. Unfortunately, this profile could not be demonstrated for the chub, which was absent from site 03004095.

We argue that this pattern analysis could help managers to set remediation priorities, in combination with the TEQ load: there might still be recent releases to the aquatic environment at sites belonging to types $\mathrm{B}$ and $\mathrm{D}$, or downstream sediments would display a relatively more recent contamination, than for sites from types $C, A$ and $E$. Therefore it seems a greater priority to clean up sources from types B or D than A, C, or E displaying similar TEQ loads, so as to speed up the recovery process. The type can be identified based on the same data that are used to estimate TEQ loads and classify a site in terms of compliance with the regulatory limit in fish. This would therefore allow managers to form an idea of remediation priorities at no additional cost. Theoretically, bottom sediments could be used for the same purpose, but sediment monitoring data are generally restricted to seven congeners $(28,52,101,118,138$, 153 and 180), which in practice hampers pattern analysis.

\section{CONCLUSION}

Fish ecological traits are important factors for explaining PCB bioaccumulation, conveniently summarised in two categories: species prone to accumulate PCBs, mostly benthic feeding, namely eel, barbel, common bream, silver bream, common carp and giant catfish; the group accumulating less these compounds includes species which are more pelagic and/or have more opportunistic or herbivorous feeding behaviours: chub, pike, roach, nase, crucian carp and tench. Fish size is another important factor explaining PCB accumulation.

Species show distinct congener patterns, related more to their physiology and metabolism than to their ecological traits. These patterns are not related to species accumulation propensity, but rather to fish physiology and metabolism, with some nuances: the profile observed in river trout can also be related to its higher position in catchments, in areas subject to atmospheric deposition.

Spatial patterns were then studied for the most current species, namely chub and barbel, with a sufficient number of samples per site available. Unfortunately this restricted the analysis to a few sites for each of these species. We identified six patterns, which mainly differed by the respective proportions of congeners potentially biotransformed by fish. No connection to typical sources, e.g. technical mixtures was identified. Rather than typical (industrial) sources, these patterns thus represent an ageing path of the initial mixtures, with decreasing proportions of biotransformable congeners. These patterns may nevertheless help managers to set 
priorities, in combination with TEQ loads: at an equivalent TEQ load, it appears a greater priority to clean up sites with more recent releases, so as to speed up the recovery process. In order to improve future monitoring or site diagnosis studies, the sampling design should focus on a more limited number of species, in particular the chub and the barbel, thus allowing better comparison of sites and spatial contamination patterns.

\section{ACKNOWLEDGEMENTS}

This work was funded by ONEMA, the French National Agency for Water and Aquatic Environments, in the context of the 2011 framework agreement with IRSTEA (formerly Cemagref), action No. 23. We thank Linda Northrup (English Solutions) for editing the manuscript.

\section{REFERENCES}

AFSSA, 2008. Appui scientifique et technique de l'Agence Française de Sécurité Sanitaire des aliments relative au plan d'échantillonnage national des PCB dans les poissons de rivière : proposition de méthodologie. Agence Française de Sécurité Sanitaire des Aliments (AFSSA), Maisons-Alfort, 10.

Ashley J.T.F., Horwitz R., Steinbacher J.C. and Ruppel B., 2003. A comparison of congeneric PCB patterns in American eels and striped bass from the Hudson and Delaware River estuaries. Mar. Pollut. Bull., 46, 1294-1308.

Babut M., Miege C., Villeneuve B., Abarnou A., Duchemin J., Marchand P. and Narbonne J.F., 2009. Correlations between dioxin-like and indicators PCBs: potential consequences for environmental studies involving fish or sediment. Environ. Pollut., 157, 3451-3456.

Babut M., Roy A., Lopes C. and Pradelle S., 2011. Contamination des poissons d'eau douce par les PCB et d'autres contaminants persistants dans le bassin Rhône-Méditerranée. Détermination de facteurs d'accumulation sédiments-poissons et d'une valeur seuil dans le sédiment au-delà de laquelle les poissons risquent de dépasser le seuil réglementaire de consommation. Cemagref DREAL Rhône-Alpes, Délégation de bassin, Lyon, p. 84.

Babut M., Lopes C., Pradelle S., Persat H. and Badot P.-M., 2012. BSAFs for freshwater fish and derivation of a sediment quality guideline for PCBs in the Rhone basin, France. J. Soils Sediments, 12, 241-251.

Bhavsar S.P., Fletcher R., Hayton A., Reiner E.J. and Jackson D.A., 2007a. Composition of Dioxin-like PCBs in Fish: An Application for Risk Assessment. Environ. Sci. Technol., 41, 3096-3102.

Bhavsar S.P., Hayton A., Reiner E.J. and Jackson D.A., 2007b. Estimating Dioxin-like polychlorinated biphenyl Toxic Equivalents from total polychlorinated biphenyl measurements in fish. Environ. Toxicol. Chem., 26, 1622-1628.

Bhavsar S.P., Jackson D.A., Hayton A., Reiner E.J., Chen, T. and Bodnar J., 2007c. Are PCB levels in fish from the Canadian Great Lakes still declining? J. Great Lakes Res., 33, 592-605.

Boon J.P., Eijgenraam F. and Everaarts J.M., 1989. A structure-activity relationship (SAR) approach towards metabolism of PCBs in marine animals from different trophic levels. Mar. Environ. Res., 27, 159-176.

Boon J.P., Oostingh I., Van Der Meer J. and Hillebrand M.T.J., 1994. A model for the bioaccumulation of chlorobiphenyl congeners in marine mammals. Eur. J. Pharmacol., 270, 237-251.

Boon J.P., Van Der Meer J., Allchin C.R., Law R.J., Klungsøyr J., Leonards P.E.G., Spliid H., Storr-Hansen E., McKenzie C. and Wells D.E., 1997. Concentration-dependent changes of PCB patterns in fisheating mammals: Structural evidence for induction of cytochrome P450. Arch. Environ. Contam. Toxicol., 33, 298-311.

Buckman A.H., Wong C.S., Chow E.A., Brown S.B., Solomon K.R. and Fisk A.T., 2006. Biotransformation of polychlorinated biphenyls (PCBs) and bioformation of hydroxylated PCBs in fish. Aquat. Toxicol., 78, 176-185.

Buckman A.H., Brown S.B., Small J., Muir D.C.G., Parrott J., Solomon K.R. and Fisk A.T., 2007. Role of temperature and enzyme induction in the biotransformation of polychlorinated biphenyls and bioformation of hydroxylated polychlorinated biphenyls by rainbow trout (Oncorhynchus mykiss). Environ. Sci. Technol., 41, 3856-3863. 
Butt C.M., Mabury S.A., Kwan M., Wang X. and Muir D.C.G., 2008. Spatial trends of perfluoroalkyl compounds in ringed seals (Phoca hispida) from the Canadian arctic. Environ. Toxicol. Chem., 27, 542-553.

Bzdusek P.A., Christensen E.R., Lee C.M., Pakdeesusuk U. and Freedman D.L., 2006a. PCB congeners and dechlorination in sediments of Lake Hartwell, South Carolina, determined from cores collected in 1987 and 1998. Environ. Sci. Technol., 40, 109-119.

Bzdusek P.A., Lu J.H. and Christensen E.R., 2006b. PCB congeners and dechlorination in sediments of Sheboygan River, Wisconsin, determined by matrix factorization. Environ. Sci. Technol., 40, 120-129.

Carlson D.L., Vault D.S.D. and Swackhamer D.L., 2010. On the Rate of Decline of Persistent Organic Contaminants in Lake Trout (Salvelinus namaycush) from the Great Lakes, 1970-2003. Environ. Sci. Technol., 44, 2004-2010.

Clark K.E., Gobas F.A.P.C. and Mackay D., 1990. Model of organic chemical uptake and clearance by fish from food and water. Environ. Sci. Technol., 24, 1203-1213.

Clarke J.U., 1986. Structure-activity relationships in PCBs: use of principal components analysis to predict inducers of mixed-function oxidase activity. Chemosphere, 15, 275-287.

Du S., Belton T.J. and Rodenburg L.A., 2008. Source apportionment of polychlorinated biphenyls in the tidal Delaware River. Environ. Sci. Technol., 42, 4044-4051.

E.C., 1996. Council Directive 96/59/EC on the disposal of polychlorinated biphenyls and polychlorinated terphenyls (PCB/PCT). In: Commission E. (ed.). Official Journal of the European Communities, 5.

E.C., 2002. Commission Directive 2002/69/EC laying down the sampling methods and the methods of analysis for the official control of dioxins and the determination of dioxin-like PCBs in foodstuffs 209/205-209/214.

E.C., 2006. Commission Directive 2006/13/EC of 3 February 2006 amending Annexes I and II to Directive 2002/32/EC of the European Parliament and of the Council on undesirable substances in animal feed as regards dioxins and dioxin-like PCBs. Official Journal of the European Union, 32/44-32/53.

E.C., 2011. Commission Regulation (EU) No 1259/2011 of 2 December 2011 amending Regulation (EC) No 1881/2006 as regards maximum levels for dioxins, dioxin-like PCBs and non dioxin-like PCBs in foodstuffs. In: Commission E. (ed.), p. 6.

Eaufrance, Site des données du plan national d'actions sur les PCB. Système d'Information sur l'Eau Onema.

Elskus A.A., Stegeman J.J., Gooch J.W., Black D.E. and Pruell R.J., 1994. Polychlorinated biphenyl congener distributions in winter flounder as related to gender, spawning site, and congener metabolism. Environ. Sci. Technol., 28, 401-407.

Eriksson L., Andersson P.L., Johansson E. and Tysklind M., 2002. Multivariate biological profiling and principal toxicity regions of compounds: The PCB case study. J. Chemometr., 16, 497-509.

Falandysz J., Wyrzykowska B., Strandberg L., Puzyn T., Strandberg B. and Rappe C., 2002. Multivariate analysis of the bioaccumulation of polychlorinated biphenyls (PCBs) in the marine pelagic food web from the southern part of the Baltic Sea, Poland. J. Environ. Monitor., 4, 929-941.

French T.D., Campbell L.M., Jackson D.A., Casselman J.M., Scheider W.A. and Hayton A., 2006. Longterm changes in legacy trace organic contaminants and mercury in Lake Ontario salmon in relation to source controls, trophodynamics, and climatic variability. Limnol. Oceanogr., 51, 2794-2807.

Harrad S.J. and Smith D.J.T., 1997. Bioaccumulation factors (BAFs) and biota to sediment accumulation factors (BSAFs) for PCBs in pike and eels. Environ. Sci. Pollut. Res., 4, 189-193.

Hickey J.P., Batterman S.A. and Chernyak S.M., 2006. Trends of chlorinated organic contaminants in Great Lakes trout and walleye from 1970 to 1998. Arch. Environ. Contam. Toxicol., 50, 97-110.

Hinz R. and Matsumura F., 1977. Comparative metabolism of PCB isomers by three species of fish and the rat. Bull. Environ. Contam. Toxicol., 18, 631-639.

Howel D., 2007. Multivariate data analysis of pollutant profiles: PCB levels across Europe. Chemosphere, 67, 1300-1307.

Johansson E., Wold S. and Sjödin K., 1984. Minimizing effects of closure on analytical data. Anal. Chem., $56,1685-1688$.

Koppe J.G. and Keys J., 2001. PCBs and the precautionary principle. In: Harremoës P., Gee D., MacGarvin M., Stirling A., Keys J., Wynne B. and Guedes Vaz S. (eds.), Late lessons from early warnings: the precautionary principle 1896-2000. European Environment Agency, Copenhagen, 64-75. 
Li H., Drouillard K.G., Bennett E., Haffner G.D. and Letcher R.J., 2003. Plasma-Associated Halogenated Phenolic Contaminants in Benthic and Pelagic Fish Species from the Detroit River. Environ. Sci. Technol., 37, 832-839.

Logue J.M., Small M.J. and Robinson A.L., 2009. Identifying Priority Pollutant Sources: Apportioning Air Toxics Risks using Positive Matrix Factorization. Environ. Sci. Technol., 43, 9439-9444.

Looser R. and Ballschmiter K., 1998. Biomagnification of polychlorinated biphenyls (PCBs) in freshwater fish. Fresenius' J. Anal. Chem., 360, 816-819.

MacDonald C.R., Norstrom R.J. and Turle R., 1992. Application of pattern recognition techniques to assessment of biomagnification and sources of polychlorinated multicomponent pollutants, such as PCBs, PCDDs and PCDFs. Chemosphere, 25, 129-134.

MEDDTL, 2012. Base de données BASOL sur les sites et sols pollués (ou potentiellement pollués) appelant une action des pouvoirs publics, à titre préventif ou curatif Inistère de l'Ecologie, du Développement Durable, des Transports et du Logement.

Monosson E., Ashley J.T.F., McElroy A.E., Woltering D. and Elskus A.A., 2003. PCB congener distributions in muscle, liver and gonad of Fundulus heteroclitus from the lower Hudson River Estuary and Newark Bay. Chemosphere, 52, 777-787.

Muir D.C.G., 1988. Organochlorine contaminants in arctic marine food chains: Accumulation of specific polychlorinated biphenyls and chlordane-related compounds. Environ. Sci. Technol., 22, 1071-1079.

Pekney N.J., Davidson C.I., Bein K.J., Wexler A.S. and Johnston M.V., 2006. Identification of sources of atmospheric PM at the Pittsburgh Supersite, Part I: Single particle analysis and filter-based positive matrix factorization. Atmos. Environ., 40, 411-423.

R Development Core Team, 2010. R: A language and environment for Statistical computing. In: R Foundation for Statistical Computing (ed.), Vienna.

Schneider A.R., Stapleton H.M., Cornwell J. and Baker J.E., 2001. Recent declines in PAH, PCB, and toxaphene levels in the Northern Great Lakes as determined from high resolution sediment cores. Environ. Sci. Technol., 35, 3809-3815.

Skrbic B. and Durisic-Mladenovic N., 2007. Distribution of chlorinated organic pollutants in a wide variety of soils from Europe and Asia: A multivariate statistical approach. Arch. Environ. Contam. Toxicol., 52, 466-474.

Van Den Berg M., Birnbaum L., Bosveld A.T.C., Brunstrom B., Cook P., Feeley M., Giesy J.P., Hanberg A., Hasegawa R., Kennedy S.W., Kubiak T., Larsen J.C., Van Leeuwen F.X.R., Liem A.K.D., Nolt C., Peterson R.E., Poellinger L., Safe S., Schrenk D., Tillitt D., Tysklind M., Younes M., Wærn F. and Zacharewski T., 1998. Toxic equivalency factors (TEFs) for PCBs, PCDDs, PCDFs for humans and wildlife. Environ. Health Persp., 106, 775.

Van den Berg M., Birnbaum L.S., Denison M., De Vito M., Farland W., Feeley M., Fiedler H., Hakansson H., Hanberg A., Haws L., Rose M., Safe S., Schrenk D., Tohyama C., Tritscher A., Tuomisto J., Tysklind M., Walker N. and Peterson R.E., 2006. The 2005 World Health Organization reevaluation of human and mammalian toxic equivalency factors for dioxins and dioxin-like compounds. Toxicol. Sci., 93, 223.

Wong C.S., Lau F., Clark M., Mabury S.A. and Muir D.C.G., 2002. Rainbow trout (Oncorhynchus mykiss) can eliminate chiral organochlorine compounds enantioselectively. Environ. Sci. Technol., 36, 1257-1262.

Wong C.S., Mabury S.A., Whittle D.M., Backus S.M., Teixeira C., Devault D.S., Bronte C.R. and Muir D.C.G., 2004. Organochlorine Compounds in Lake Superior: Chiral Polychlorinated Biphenyls and Biotransformation in the Aquatic Food Web. Environ. Sci. Technol., 38, 84-92.

Yunker M.B., Ikonomou M.G., Sather P.J., Friesen E.N., Higgs D.A. and Dubetz C., 2011. Development and Validation of Protocols To Differentiate PCB Patterns between Farmed and Wild Salmon. Environ. Sci. Technol., 45, 2107-2115. 